\title{
Effects of fermentation and salting on the bacterial, chemical and sensory characteristics of Tilapia (Chromidototilapia guentheri) based marinate in Nigeria
}

\author{
C. F. Ezeama* and E. J. Udoh \\ Department of Food Science and Technology, Michael Okpara University of Agriculture \\ Umudike, P. M. B. 7267 Umuahia, Nigeria \\ ${ }^{*}$ Correspondence author \\ ABSTRACT
}

\begin{abstract}
Microbiological, chemical and sensory analyses were carried out on Tilapia (Chromidotilapia guentheri) treated with 10 and $15 \% \mathrm{w} / \mathrm{w} \mathrm{NaCl}$ with or without spices $(1 \% \mathrm{w} / \mathrm{w}$ garlic and $1 \% \mathrm{w} / \mathrm{w}$ red pepper) and allowed to ferment at ambient temperature $\left(28 \pm 2^{0} \mathrm{C}\right)$ for two weeks. Results indicate that fermentation and salting remarkably reduced the total bacterial count from $2.55 \times 10^{6}$ $\mathrm{cfu} / \mathrm{g}$ for the unfermented non-salted (UNF) to $4.30 \times 10^{5} \mathrm{cfu} / \mathrm{g}$ for fermented $15 \% \mathrm{w} / \mathrm{w}$ salted samples. There was reduction in $\mathrm{pH}$ from 6.86 for UNF to 4.22 for fermented spiced samples with a corresponding increase in total titratable acidity. Proximate composition indicates increases in ash and fibre contents with fermentation and salting while moisture, protein, fat and Nitrogen free extract decreased. Free fatty acid, peroxide value and total volatile base showed increased values. The predominant bacterial isolates were Staphylococcus aureus, Staphylococcus epidermidis and Lactobacillus spp. The fermented non-salted and fermented salted samples incorporated into stew showed that fermented samples treated with 10 and $15 \% \mathrm{w} / \mathrm{w} \mathrm{NaCl}$ and spices had general acceptance with significant difference $(\mathrm{P}<0.05)$ in overall acceptability and other parameters. Bacterial analysis of the fermented product revealed that it could be stored for 3 months since the total counts of bacterial isolates were still within acceptable limit.
\end{abstract}

Keywords: Tilapia, microbial, chemical, sensory, marinate, fermentation.

\section{INTRODUCTION}

Many raw fish species are sometimes derived from poor quality or underutilized species which are very cheap and affordable to many low income consumers. Some of the species have been fermented and used as foods in some parts of the world. Examples of such fermented fish products include Shushi in Japan, Patis in Philippines and Budu in Malaysia (Klinic, 2003).

In Nigeria, it is obvious that some fish species especially in the coastal areas are of smaller sizes and are underutilized. These ranges from byproducts in sea fishing to the stunted Tilapia which are often discarded in fish farms because of their numerous bones and small sizes which render them of little acceptance for human consumption, thus posing the problem of post-harvest losses. (Eyo, 2001) Furthermore, nutritional losses also occur due to spoilage or exposure of fish to high temperature during smoking especially that of traditional hot smoking and fish burning. Considering the fact that these underutilized fish species, including Tilapia (Chromidotilapia guentheri) and Catfish (Clarias buthupogon) are readily available and abundant in the Eastern part of Nigeria, they could be transformed into fermentable products which are far more stable, safer, enjoyable and with improved shelf life than the raw material.

Though fish fermentation is not common and really appreciated in Nigeria, the benefit inherent in the consumption of this product will be enormous, more especially in salvaging the fish farmers and marketers from post-harvest losses. The objective of this work is to improve the utilization of unconventional fish species through fermentation for human consumption and to determine the microbial, proximate and chemical properties of the product. The sensory properties of stew prepared with the products were also assessed. 


\section{MATERIALS AND METHODS}

Collection of samples: The fish species Chromidotilapia guentheri used in this study were bought fresh from Imo river market, Owerrinta, Abia State, stored in plastic coolers containing ice cubes and transported to the laboratory. The size of the fish species ranged between 6.7 and $9.3 \mathrm{~cm}$

Preparation of samples: The fishes were beheaded, gutted, scaled and thoroughly washed in running water and divided into five triplicate portions of $100 \mathrm{~g}$ each. One portion was unfermented non-salted fish while the second portion contains $10 \% \mathrm{w} / \mathrm{w}$ of $\mathrm{NaCl}$. The third portion had $15 \% \mathrm{w} / \mathrm{w} \mathrm{NaCl}$ while the fourth portion was treated with $10 \% \mathrm{w} / \mathrm{w} \mathrm{NaCl}$ and spices ( $1 \% \mathrm{w} / \mathrm{w}$ red pepper and $1 \% \mathrm{w} / \mathrm{w}$ garlic powder). The fifth portion was treated with $15 \% \mathrm{w} / \mathrm{w} \mathrm{NaCl}$ and spices $(1 \% \mathrm{w} / \mathrm{w}$ red pepper and $1 \% \mathrm{w} / \mathrm{w}$ garlic powder). The treated samples apart from the unfermented non-salted were placed in plastic containers, well covered and allowed to ferment at room temperature $\left(28 \pm 2^{0} \mathrm{C}\right)$ for two weeks. The $\mathrm{pH}$, total titratable acidity and total viable count were determined on the raw unfermented non-salted sample while the $\mathrm{pH}$, titratable acidity and microbiological analysis were also carried out weekly on the fermented samples. After the two weeks, the fermented samples were dried in an oven at $65^{\circ} \mathrm{C}$ for $24 \mathrm{~h}$, milled and stored in plastic containers. Further microbiological, chemical and sensory analyses (after adding to stew) were carried out.

Microbiological analysis: Isolation and enumeration of heterotrophic bacteria were carried out using the pour plate method as described by Ezeama (2007). The taxonomic schemes as described by Cowan (1985), was also used for characterization and identification of the isolate. Gram staining, spore staining and motility test were carried out for the microscopic characterization of the isolates as described by Cruickshank et al (1975).

Biochemical analysis: The biochemical test carried out were coagulase, catalase, citrate utilization, oxidase, methyl red, Voges Proskauer and carbohydrate fermentation tests as described by Cruickshank et al (1975).

Chemical anaylsis: Free Fatty Acid content, peroxide value and Total titratable acidity of the unfermented non-salted and fermented salted fish samples were determined using AOAC (2000) method while total volatile base was determined by volumetric method for the determination of volatile bases in fish as described by Pearson (1976).
Proximate composition: Moisture content was determined using AOAC (2000) while crude protein determination was carried out using kjeldahl method as described by AOAC (2000). Ash, lipid and crude fibre were estimated using AOAC (2000) while the "Difference" method was employed for the estimation of the percentage Nitrogen free Extract of each of the fish samples.

Sensory evaluation: The products incorporated into stew were subjected to sensory parameters of odour, saltiness, colour, taste and overall acceptability by employing a 5-point hedonic scale where $5=$ excellent, $4=$ very good, $3=$ good, $2=$ fair and $1=$ poor as described by Achinewhu and Oboh (2002).

Statistical analysis: Analysis of variance (ANOVA) in completely randomized design was performed on the data obtained using SPSS (2006). Significant means were compared at $5 \%$ probability level using Duncan's Multiple Range Test (DMRT) as provided in the same SPSS (2006).

\section{RESULTS AND DISCUSSION}

Table 1 shows the total bacterial count, $\mathrm{pH}$ and total titratable acidity (TTA) of unfermented non salted and fermented salted Tilapia (Chromidotilapia guentheri). The total bacterial count for unfermented non salted Chromidotilapia guentheri was observed to be $2.55 \times 10^{6} \mathrm{cfu} / \mathrm{g}$. This was attributed to the possession of fish scales that inhabit microorganisms. The bacterial load however reduced significantly to $4.30 \times 10^{5} \mathrm{cfu} / \mathrm{g}$ at the end of fermenting $15 \% \mathrm{w} / \mathrm{w}$ salted and spiced sample. A reduction in $\mathrm{pH}$ from 6.86 for unfermented to 4.22 for $10 \% \mathrm{w} / \mathrm{w}$ salted and spiced samples were observed while the total titratable acidity increased correspondingly from 0.63 for unfermented to 1.43 for fermented $10 \% \mathrm{w} / \mathrm{w}$ salted samples. This significant decrease in $\mathrm{pH}$ with a corresponding increase in total titratable acidity could be attributed to the utilization of carbohydrate produced in the medium by Lactobacillus $s p$. causing the production of lactic acid with a strong effect of reducing the $\mathrm{pH}$ and increasing the total titratable acidity. The reduction in bacterial load could be attributed to the reduction in $\mathrm{pH}$ which affected enzyme function making the environment acidic and destructive to some bacteria that cannot survive this condition. The two main factors controlling food poisoning bacteria in fermented fish products as reported by Erichen (1983) were high salt concentration and low $\mathrm{pH}$ values. It was also observed that the fermented samples with $15 \% \mathrm{w} / \mathrm{w}$ salt and spices (1\%w/w red pepper and $1 \% \mathrm{w} / \mathrm{w}$ garlic 
powder) had relatively low bacterial count. According to Akande et al, (1991) the presence of spices which are bactericidal in nature may have accounted for the low counts obtained.

Table 1 Total Bacterial Count, pH and Total Titratable Acidity of Fermented Tilapia (Chromidotilapia guentheri)

Total bacterial count (CFU/g)

$\mathrm{pH}$

TTA (\%) lactic Acid

Fermentation period (weeks)

\begin{tabular}{|c|c|c|c|c|c|c|}
\hline Samples & 1 & 2 & 1 & 2 & 1 & 2 \\
\hline \multicolumn{7}{|c|}{$\begin{array}{l}\text { Unfermented } \\
\text { non salted }\end{array}$} \\
\hline Fish & $2.55 \times 10^{\mathrm{a}} \pm 0.10^{6}$ & - & $7.29 \pm 0.06^{\mathrm{a}}$ & - & $0.63 \pm 0.11$ & - \\
\hline A & $1.40 \pm 0.10^{b} \times 10^{6}$ & $1.13 \pm 85^{b} \times 10^{6}$ & $4.88 \pm 0.07^{b}$ & $4.53 \pm 0.13^{\mathrm{bc}}$ & $1.2 \pm 0.11^{\mathrm{b}}$ & $1.43 \pm 0.09^{\mathrm{a}}$ \\
\hline B & $1.21 \pm 0.09^{b} \times 10^{6}$ & $6.7 \pm 10^{C} \times 10^{5}$ & $4.30 \pm 0.75^{\mathrm{C}}$ & $4.22 \pm 0.02^{c}$ & $1.26 \pm 0.04^{\mathrm{a}}$ & $1.35 \pm 0.11^{\mathrm{a}}$ \\
\hline$\vec{C}$ & $1.25 \pm 0.10^{\mathrm{b}} \times 10^{6}$ & $1.02 \pm 0.11^{b} \times 10^{6}$ & $4.77 \pm 0.80^{b}$ & $4.41 \pm 0.09^{\mathrm{bc}}$ & $1.24 \pm 0.03^{\mathrm{a}}$ & $1.29 \pm 0.10^{\mathrm{a}}$ \\
\hline D & $1.03 \pm 0.17^{b} \times 10^{6}$ & $4.3 \pm 0.04^{\mathrm{C}} \times 10^{5}$ & $4.7 \pm 0.12^{\mathrm{b}}$ & $4.61 \pm 0.10^{\mathrm{a}}$ & $1.23 \pm 0.10^{\mathrm{a}}$ & $1.34 \pm 0.07^{\mathrm{a}}$ \\
\hline
\end{tabular}

Means on the same row with different superscripts are significantly different at $(p<0.05)$.

Values are means of three determinations.

Sample means \pm SEM

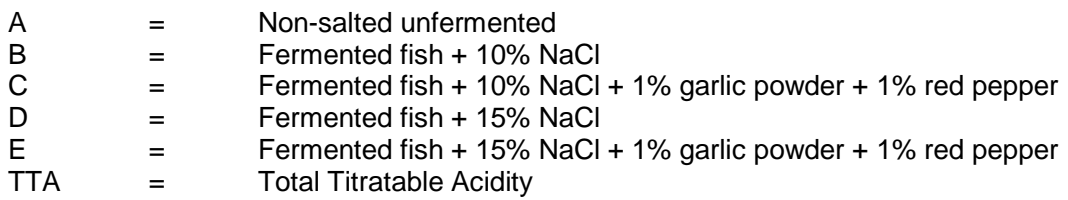

The chemical composition of the fermented tilapia (Chromidotilapia guentheri) presented in table 2 showed that there was significant decrease in moisture content with fermentation. The moisture content decreased from $77.97 \%$ (fermented nonsalted) to $72.44 \%$ for fermented $15 \% \mathrm{w} / \mathrm{w}$ salted samples. This could be attributed to the use of salt that extracted moisture from the fish tissues as a result of reduction of water activity through osmosis. The moisture content of Chromidotilapia guentheri showed a significant difference $(P<0.05)$ between the fermented salted and unfermented non salted (fresh) samples. The crude protein content of Chromidotilapia guentheri ranged between 68.01 (unfermented non salted) to $64.32 \%$ for fermented $10 \%$ salt samples. This decrease could be attributed to proteolytic enzymes. Salting treatment decreased the protein of the fermented fish product as a result of protein being dissolved in the brine and other nitrogenous substance including free amino acids (Clucas and Ward 1996). The lipid content showed a slight decrease from $13.70 \%$ (unfermented nonsalted) to $13.06 \%$ for the fermented $15 \% \mathrm{w} / \mathrm{w}$ salted and spiced fish samples. This slight decrease in lipid content with fermentation and salting is an indication that the fermented fish produce could store for long period than the fresh at the right temperature and moisture without spoilage. However the lipid content of fermented fish varied with species. The ash content increased from $12.10 \%$ (unfermented and non-salted) to $14.10 \%$ for fermented $15 \% \mathrm{w} / \mathrm{w}$ salted samples. This was attributed to salt up take during fermentation as reported by FAO (1992). The ash and lipid contents of Tilapia Chromidotilapia guentheri showed no significant differences $(P<0.05)$ among the samples.

Table 3 shows the result of free fatty acid, peroxide value and total volatile base. Peroxide value increased from $4.02 \mathrm{mEq} / \mathrm{kg}$ to $8.63 \mathrm{mEq} / \mathrm{kg}$ with the unfermented non salted sample having the lowest value while the fermented $15 \% \mathrm{w} / \mathrm{w}$ salted had the highest. Peroxide value is usually a measure for the estimation of degree of rancidity of food products. Though the peroxide value of fish product increased with fermentation and salting, it was still without any adverse effect on the quality of the product. Eyo (2001) had reported that the peroxide values corresponding to incipient spoilage are usually in the order of $20-40 \mathrm{mEq} / \mathrm{kg}$ of sample. Slight increase was observed in the free fatty acid of non salted unfermented and fermented salted product of tilapia (Chromidotilapia guentheri). This was in agreement with the work of Achinewhu and Oboh 2002 who 
attributed the little increase in free fatty acid during fermentation of Sardinella $s p$. to the effects of salt and curing mixture (spices). Total volatile Base (TVB) also increased during fermentation of Tilapia (Chromidotilapia guentheri) ranging between $4.28 \mathrm{mgN} / 100 \mathrm{~g}$ and $14.72 \mathrm{mgN} / 100 \mathrm{~g}$ for the non salted unfermented and fermented salted samples respectively. The total volatile base content obtained agreed with the finding of Klinic (2003) who reported increase in TVB of salted fermented Sardinella brasiliensis. The result obtained from the fresh unfermented non salted fish was a good index of freshness of the raw material. There was significant difference $(\mathrm{P}<0.05)$ in free fatty acid, peroxide value and total volatile Base contents between the non salted unfermented and fermented salted samples of Tilapia (Chromidotilapia guenther).

The spatial occurrence or distribution of bacterial isolate in fermented tilapia (Chromidotilapia guentheri) as shown on Table 4 revealed that Lactobacillus spp., Bacillus sp., Proteus, Staphylococcus aureus, Staphylococcus epidermidis were isolated from the unfermented non-salted (fresh) Chrormidotilapia guentheri but during fermentation, the growth of Proteus was no longer observed but Bacillus sp was sparingly observed. While Lactobacillus spp., Staphylococcus aureus, Staphylococcus epidermidis were the predominant bacterial isolates during the first week of fermentation. the growth of Bacillus $s p$ was no longer observed in the fermenting sample of the fish (Chromidotilapia guentheri) during the second week of fermentation but the growth of Lactobacillus spp, Staphylococcus aureus and Staphylococcus epidermidis. According to Oetterer (2003), Staphylococcus aureus is quite resistant to high salinity, surviving in media up to $20 \%$ salt $(\mathrm{NaCl})$.

Table 2 Proximate Composition (\%) of Fermented Tilapia (Chromidotilapia guentheri)

Fish Samples

\begin{tabular}{lllcll}
\hline Nutrients (\%) & A & B & C & D & E \\
\hline Moisture & $77.97 \pm 0.72^{\mathrm{a}}$ & $73.35 \pm 0.12^{\mathrm{b}}$ & $73.46 \pm 0.01^{\mathrm{b}}$ & $72.4 \pm 0.21^{\mathrm{b}}$ & $72.61 \pm 0.27^{\mathrm{b}}$ \\
Protein & $68.01 \pm 0.19^{\mathrm{a}}$ & $66.63 \pm 0.14^{\mathrm{b}}$ & $65.39 \pm 0.37^{\mathrm{c}}$ & $64.32 \pm 0.24^{\mathrm{c}}$ & $64.39 \pm 0.42^{\mathrm{a}}$ \\
Fat & $13.70 \pm 0.23^{\mathrm{a}}$ & $13.20 \pm 0.50^{\mathrm{a}}$ & $13.25 \pm 0.37^{\mathrm{a}}$ & $12.36 \pm 0.11^{\mathrm{a}}$ & $13.06 \pm 0.62^{\mathrm{a}}$ \\
Ash & $12.10 \pm 0.35^{\mathrm{a}}$ & $12.20 \pm 0.14^{\mathrm{a}}$ & $13.51 \pm 0.12^{\mathrm{z}}$ & $14.10 \pm 0.28^{\mathrm{a}}$ & $13.98 \pm 0.77^{\mathrm{a}}$ \\
NFE & $7.2 \pm 0.63^{\mathrm{a}}$ & $8.0 \pm 0.28^{\mathrm{a}}$ & $7.8 \pm 0.31^{\mathrm{a}}$ & $8.2 \pm 0.56^{\mathrm{a}}$ & $8.6 \pm 0.68^{\mathrm{a}}$ \\
& & & & & \\
\hline
\end{tabular}

Means on the same row with different superscripts are significantly different at $(p<0.05)$. Values are means of three determinations.

Sample means \pm SEM

$\begin{array}{lll}A & = & \text { Non-salted unfermented } \\ \mathrm{B} & = & \text { Fermented fish }+10 \% \mathrm{NaCl} \\ \mathrm{C} & = & \text { Fermented fish }+10 \% \mathrm{NaCl}+1 \% \text { garlic powder }+1 \% \text { red pepper } \\ \mathrm{D} & = & \text { Fermented fish }+15 \% \mathrm{NaCl} \\ \mathrm{E} & = & \text { Fermented fish }+15 \% \mathrm{NaCl}+1 \% \text { garlic powder }+1 \% \text { red pepper } \\ \mathrm{NFE} & = & \text { Nitrogen Free Extract }\end{array}$


Am. J. Food. Nutr, 2012, 2(1): 7-13

Table 3 Free Fatty Acid, Peroxide Value and Total Volatile Base of Fermented tilapia (Chromidotilapia guentheri)

Fish Samples

\begin{tabular}{lccccc}
\hline Parameter & A & B & C & D & E \\
\hline $\begin{array}{l}\text { Free fatty } \\
\text { acid (\%) }\end{array}$ & $14.36 \pm 0.05^{\mathrm{b}}$ & $15.46 \pm 0.05^{\mathrm{b}}$ & $13.64 \pm 0.11^{\mathrm{c}}$ & $14.30 \pm 0.55^{\mathrm{b}}$ & $13.44 \pm 0.003^{\mathrm{c}}$ \\
$\begin{array}{l}\text { Peroxide } \\
\text { value } \\
\mathbf{m} / \mathbf{E q} / \mathbf{k g}\end{array}$ & $4.02 \pm 0.10^{\mathrm{e}}$ & $7.21 \pm 0.11^{\mathrm{b}}$ & $6.42 \pm 0.08^{\mathrm{d}}$ & $8.63 \pm 0.07^{\mathrm{a}}$ & $6.82 \pm 0.08^{\mathrm{c}}$ \\
$\begin{array}{l}\text { Total volatile } \\
\text { base } \\
\text { (MgN/100g) }\end{array}$ & $4.28 \pm 0.15^{\mathrm{d}}$ & $14.72 \pm 0.10^{\mathrm{a}}$ & $14.02 \pm 0.10^{\mathrm{b}}$ & $13.73 \pm 0.11^{\mathrm{b}}$ & $13.31 \pm 0.85$ \\
\hline
\end{tabular}

Means on the same row with different superscripts are significantly different at $(p<0.05)$.

Values are means of three determinations.

Sample means \pm SEM

$\begin{array}{lll}\mathrm{A} & = & \text { Non-salted unfermented } \\ \mathrm{B} & = & \text { Fermented fish }+10 \% \mathrm{NaCl} \\ \mathrm{C} & = & \text { Fermented fish }+10 \% \mathrm{NaCl}+1 \% \text { garlic powder }+1 \% \text { red pepper } \\ \mathrm{D} & = & \text { Fermented fish }+15 \% \mathrm{NaCl} \\ \mathrm{E} & = & \text { Fermented fish }+15 \% \mathrm{NaCl}+1 \% \text { garlic powder }+1 \% \text { red pepper }\end{array}$

Table 4 Spatial Occurrence of Bacterial Isolates in Fermented Tilapia (Chromidotilapia guentheri)

\begin{tabular}{|c|c|c|c|c|c|c|c|c|c|c|c|}
\hline \multirow[b]{2}{*}{$\begin{array}{l}\text { Isolated } \\
\text { organisms }\end{array}$} & \multicolumn{5}{|c|}{ Week 1 fermented sample } & \multicolumn{5}{|c|}{ Week 2 fermented sample } & \\
\hline & UNF & $A$ & $\mathrm{~B}$ & $\mathrm{C}$ & $\mathrm{D}$ & & $A$ & $\mathrm{~B}$ & C & $\mathrm{D}$ & \\
\hline Staph.aureus + & + & & + & + & - & & + & - & + & - & \\
\hline Staph. epidermidis & + & & - & + & + & - & & + & + & + & + \\
\hline Bacillus sp & + & & + & - & + & + & & - & - & - & - \\
\hline Lactobacillus spp + & + & & + & + & + & & + & + & + & + & \\
\hline Proteus sp & + & & - & - & - & - & & - & - & - & - \\
\hline
\end{tabular}

$\begin{array}{lll}\mathrm{A} & = & \text { Fermented fish } 10 \% \mathrm{NaCl} \\ \mathrm{B} & = & \text { Fermented fish } 10 \% \mathrm{NaCl}+1 \% \text { garlic powder }+1 \% \text { red pepper } \\ \mathrm{C} & = & \text { Fermented fish }+15 \% \mathrm{NaCl} \\ \mathrm{D} & = & \text { Fermented fish }+15 \% \mathrm{NaCl}+1 \% \text { garlic powder }+1 \% \text { red pepper } \\ \mathrm{UNF} & = & \text { Unfermented non-salted }\end{array}$

Table 5 shows the sensory evaluation of stew with fermented salted and unfermented non-salted tilapia (Chromidotilapia guentheri). The result revealed that stew containing fermented samples treated with $10 \% \mathrm{w} / \mathrm{w} \mathrm{NaCl}$ and spices as condiment were preferred. These samples recorded significantly higher score in all the parameters tested. This could be attributed to the use of garlic and red pepper (spices) during the fermentation.
Microbiological analysis was carried out on the product after fermentation and during the first three months of storage (Table 6). There was remarkable reduction in total bacterial count from $2.60 \times 10^{5} \mathrm{cfu} / \mathrm{g}$ (unfermented non-salted) to $<10^{1} \mathrm{cfu} / \mathrm{g}$ for fermented $15 \% \mathrm{w} / \mathrm{w}$ salted sample at 0 month of storage. However, by the $3^{\text {rd }}$ month, the fermented $15 \% \mathrm{w} / \mathrm{w}$ $\mathrm{NaCl}$ spiced sample had the lowest bacterial load $\left(1.32 \times 10^{5} \mathrm{cfu} / \mathrm{g}\right)$ followed by that of $10 \% \mathrm{NaCl}$ spiced sample. The unfermented non-salted had 
unacceptable bacterial load by the $3^{\text {rd }}$ month $\left(1.06 \times 10^{6} \mathrm{cfu} / \mathrm{g}\right)$. The antimicrobial property of spices may have contributed to the acceptable microbial quality of the spiced treated samples by the $3^{\text {rd }}$ month. There was no fungal growth on the salted spiced samples by the $3^{\text {rd }}$ month. However, the results of the microbiological analysis obtained within the 3 months of storage and evaluation of these products were within the limits of $10^{7} \mathrm{cfu} / \mathrm{g}$ specified for quality grading of fish by the International Commission of Microbiological Standards for Foods (ICMSF, 1996) suggesting that the products could be stored beyond 3 months.

Table $5 \quad$ Mean Sensory Score of stewed Tilapia (Chromidotilapia guentheri)

\section{Fish Samples}

\begin{tabular}{|c|c|c|c|c|c|}
\hline $\begin{array}{l}\text { Sensory } \\
\text { attributes }\end{array}$ & A & B & C & D & E \\
\hline Colour & $3.40 \pm 0.50^{b}$ & $3.31 \pm 0.00^{b}$ & $3.55 \pm 0.10^{b}$ & $3.72 \pm 0.95^{\mathrm{ab}}$ & $4.23 \pm 0.35^{\mathrm{a}}$ \\
\hline Odour & $3.08 \pm 0.14^{b}$ & $3.64 \pm 0.10^{\mathrm{a}}$ & $2.93 \pm 0.50^{b}$ & $3.63 \pm 0.85^{a}$ & $3.67 \pm 0.11^{\mathrm{a}}$ \\
\hline Saltiness & $3.41 \pm 0.25^{\mathrm{a}}$ & $3.63 \pm 0.11^{\mathrm{a}}$ & $3.44 \pm 0.12^{\mathrm{a}}$ & $3.69 \pm 0.95^{\mathrm{a}}$ & $2.07 \pm 0.90^{b}$ \\
\hline $\begin{array}{l}\text { Overall } \\
\text { acceptability }\end{array}$ & $3.39 \pm 0.05^{\mathrm{a}}$ & $3.84 \pm 0.85^{\mathrm{a}}$ & $3.16 \pm 0.50^{\mathrm{a}}$ & $3.43 \pm 0.11^{\mathrm{a}}$ & $1.40 \pm 0.05^{b}$ \\
\hline
\end{tabular}

Mean on the same row with different superscripts are significantly different $(p<0.05)$.

Values are means of three determinations.

Sample means \pm SEM

$\begin{array}{lll}\mathrm{A} & = & \text { Stew with fermented fish }+10 \% \mathrm{NaCl} \\ \mathrm{B} & = & \text { Stew with fermented fish }+10 \% \mathrm{NaCl}+1 \% \text { garlic powder }+1 \% \text { red pepper } \\ \mathrm{C} & = & \text { Stew with fermented fish }+15 \% \mathrm{NaCl} \\ \mathrm{D} & = & \text { Stew with fermented fish }+15 \% \mathrm{NaCl}+1 \% \text { garlic powder }+1 \% \text { red pepper } \\ \mathrm{E} & = & \text { Stew with unfermented and non salted fish }\end{array}$

Table 6 Total Bacterial Count and Fungal Counts of Fermented Tilapia (Chromidotilapia guentheri) Total bacterial count (CFU/g) Total fungal counts (CFU/g)

\begin{tabular}{lcccccccc} 
Samples & \multicolumn{7}{c}{ Storage period (months) } \\
\cline { 2 - 8 } & $\mathbf{0}$ & 1 & 2 & 3 & 0 & 1 & 2 & 3 \\
\hline UNF & $2.60 \times 10^{5}$ & $4.82 \times 10^{5}$ & $6.91 \times 10^{5}$ & $1.06 \times 10^{6}$ & - & - & - & $3.01 \times 10^{4}$ \\
A & $5.01 \times 10^{4}$ & $1.83 \times 10^{5}$ & $2.74 \times 10^{5}$ & $4.12 \times 10^{5}$ & - & - & - & $2.00 \times 10^{4}$ \\
B & $4.00 \times 10^{4}$ & $7.03 \times 10^{4}$ & $1.51 \times 10^{5}$ & $2.32 \times 10^{5}$ & - & - & - & - \\
C & $2.03 \times 10^{4}$ & $9.02 \times 10^{4}$ & $2.13 \times 10^{5}$ & $3.71 \times 10^{5}$ & - & - & - & $<10^{1}$ \\
D & $<10^{1}$ & $5.04 \times 10^{4}$ & $8.02 \times 10^{4}$ & $1.32 \times 10^{5}$ & - & - & - & -
\end{tabular}

Values are means of three determinations.

$\begin{array}{lll}\mathrm{A} & = & \text { Fermented fish }+10 \% \mathrm{NaCl} \\ \mathrm{B} & = & \text { Fermented fish }+10 \% \mathrm{NaCl}+1 \% \text { garlic powder }+1 \% \text { red pepper } \\ \mathrm{C} & = & \text { Fermented fish }+15 \% \mathrm{NaCl} \\ \mathrm{D} & = & \text { Fermented fish }+15 \% \mathrm{NaCl}+1 \% \text { garlic powder }+1 \% \text { red pepper } \\ \mathrm{UNF} & = & \text { Unfermented non-salted }\end{array}$


CONCLUSION: The result obtained from this study revealed a high degree of freshness of the raw materials used and also showed that fermented product from tilapia (Chromidotilapia guentheri) would not constitute or pose any health hazard. It has also proved that fermentation; salting spicing and drying could be used effectively as processing methods to develop products that are new and safer with extended shelf- life. Fermented fish products are not eaten as such but are used either as condiment to enhance food flavour or as food fish and a source of protein.

\section{REFERENCES}

Achinewhu, S. C. and Oboh, C. A. (2002) Chemical, Microbiological and Sensory Properties of Fermented Fish Product from Sardinella sp. in Nigeria, Journal of Aquatic Product Technology 11 (2)53-59

Akande, G. R., Towuru, E. T. and Ogbonna, C. (1991) Production, Acceptability and Storage Characteristics of Spiced Plinced Fish Cakes from by Catches. Proceeding of FAO Fisheries Report 467, Accra, Ghana

Association of Official Analytical Chemist (AOAC) (2000) Official Method of Analysis $17^{\text {th }}$ edn. Washington DC, USA.

Cowan, S. T. (1985) Manual for Identification of Medical Bacteria ( $2^{\text {nd }}$ Edition) Cambridge University Press Britain.

Cruickshank, R., Duguid, J. P. Marmion, B. P., Swain, R. H. A., (1975). Medical Microbiology. The Practice of Medical Microbiology. $12^{\text {th }} \mathrm{Ed}$, Vol. 11 Churchill, Livingstone, Edinburgh. London and New York.

Clucas I. J. and Ward, A. R. (1996) Post Harvest Fisheries Development: A Guide to Handling, Preservation,
Processing and Quality, Natural Resources Institute (NRI)

Erichen, I. (1983) Fermented meat and fish products. "The Present Position and Future Possibilities" Sweedes Meat Research Institute kavling Sweden

Eyo, A. A. (2001) fish Processing Technology in the Tropics, National Institute for Fresh Water Fisheries Research (FIFR) New Bussa Nigeria pp 66-130

Ezeama, C. F. (2007) Food Microbiology, Fundamentals and Applications, Natural Points Limited Lagos, Nigeria, pages 64-66,104

Food and Agriculture Organization FAO (1992) Fermented Fish in Africa, a. Study on Processing, Marketing and Composition. FAO Fisheries Technical Paper no 329 Rome, Italy

International Commission of Microbiological Specification for Food (ICMSF) (1996) Seafood Toxins of Microbiological Origin, Micro Organism in Food Vol. 5 Microbiological Specification of Food Pathogens, London, 265-279.

Klinic, B (2003) Fish sauce Technology. EUJ Fish aquatic Sciences. 20(1 \& 2): $263-273$.

Oetterer, M. Perijo, S. D. and Gallo, C. R. (200) Monitoring the Sardine (Sardinella brasilienses) Fermentation Process to Obtain Anchovies, Journal of Sc. Agric 60 (3) $511-513$

Okon, E. U. (2005) Handbook of Basic Handbook of Basic Food ands Beverage Analysis, Etovin Publisher, Uyo, Nigeria. pp 53-69

Pearson, D. A. (1976) Chemical Analyses of Foods $7^{\text {th }}$ Edition Churchill Livingstone Edinburg.

SPSS(2006) SPSS 15.0 for window evaluation version. Statistical Package for Social Sciences. SPSS Inc 